Viewpoint

\title{
Exploring Tools for Public Real Estate Enhancement in Italy: From Criteria to Decisions
}

\author{
Marzia Morena ${ }^{1}$, Genny Cia ${ }^{1}\left[\right.$, Alessandra Migliore ${ }^{1,2, *} \mathbb{D}$ and Stefano Mantella ${ }^{3}$ \\ 1 Department of Architecture, Built Environment and Construction Engineering, Politecnico di Milano, \\ Via Bonardi 9, 20133 Milan, Italy; marzia.morena@polimi.it (M.M.); genny.cia@polimi.it (G.C.) \\ 2 Department of Management, Economics and Industrial Engineering, Politecnico di Milano, \\ Via Lambruschini 4/b, 20156 Milan, Italy \\ 3 Department of Real Estate Strategies and Innovation, Agenzia del Demanio, Via Barberini 38, 00187 Rome, \\ Italy; stefano.mantella@agenziademanio.it \\ * Correspondence: alessandra.migliore@polimi.it; Tel.: +39-3349454915
}

Citation: Morena, M.; Cia, G.; Migliore, A.; Mantella, S. Exploring Tools for Public Real Estate Enhancement in Italy: From Criteria to Decisions. Sustainability 2021, 13, 622. https://doi.org/10.3390/ su13020622

Received: 28 November 2020 Accepted: 7 January 2021 Published: 11 January 2021

Publisher's Note: MDPI stays neutral with regard to jurisdictional clai$\mathrm{ms}$ in published maps and institutional affiliations.

Copyright: (C) 2021 by the authors. Licensee MDPI, Basel, Switzerland. This article is an open access article distributed under the terms and conditions of the Creative Commons Attribution (CC BY) license (https:// creativecommons.org/licenses/by/ $4.0 /)$.

\begin{abstract}
The debate on public real estate enhancement is prominent and requires innovative strategies to assure economic and social sustainability. This article aims at systematizing the currently available methods and tools of public property enhancement in Italy, proposing a system of criteria to support the public administration (PA) in the decision-making process when managing public real estate enhancement oriented towards public utility. Namely, this article considers and assesses consolidated and innovative public real estate enhancement methods and tools currently available to the Italian PA according to the "endogenous criteria" of the real estate tools and "criteria of purpose" of the public administration promoting the enhancement process. The final aim is to support the decision-making process of PAs and help both public and private actors in grasping and managing the complexity of public real estate enhancement. An overview of the literature and of reference laws on public property enhancement builds the research framework, together with a path of research, dialogues, and fieldworks with the Italian State Property Agency (Agenzia del Demanio). The decision-making process of PAs for selecting a suitable enhancement strategy or tool should rest on endogenous criteria and criteria of purpose. Specifically: (i) the distinct technical features of each public asset; (ii) the public utility aim that the public entity intends to pursue; (iii) the needs of the community (i.e., the demand); (iv) the skills available within the PA that promotes the strategy.
\end{abstract}

Keywords: public property; public utility; public real estate management; enhancement of public real estate; public assets; decision-making; effectiveness; economy; efficiency

\section{Public Real Estate Enhancement: Lost in Translation?}

The management and enhancement of public real estate is a relevant issue of collective importance that requires policy makers, representatives of public administrations (PAs), and private stakeholders to provide effective answers and models for interpretation, design and management, especially at a local level [1,2]. This research starts from the assumptionstill ongoing among few scholars, e.g., [3] — that the publicness of public real estate depends more on its public utility than on its State ownership. That is to say, the main objective of managing public real estate is to effectively and efficiently use the assets, allowing the process of performing public tasks [2], and thus meeting the collective needs of the community by providing local public goods.

This assumption deals with the conviction that public real estate assets are enclosed in the 'Public Goods system'. A public good is an asset that belongs to the State or to other public bodies and to the community [4] and is intended as an instrument by which the PA achieves its purposes. The concept of public good has deep roots in the scientific literature: Paul Samuelson's research entitled "The Pure Theory of Public Expenditure" [5] expressed the concept of "pure" public goods according to three funding principles. Firstly, 
these goods are the expression of the highest degree of "publicness"; secondly maximum accessibility and inclusion in the use and consumption of public goods should be ensured; finally, the consumption of the good by an individual is supposed to not limit its consumption by others (non-rivalry principle). These concepts are reported also among the UN sustainability goals [6] and contribute radically to the concept of sustainability. However, public real estate management is a complex system of procedures that evolved over time and involves a plurality of subjects, approaches and interpretations that must leverage the above-mentioned principles. The first sources of complexity come not only from its country-specificities, but also from the diversified stakeholders involved [3]. Indeed, the approach towards public real estate management varies based on context, political sensitivity, and the managerial and technical skills of the subjects-public or private-involved. Over the past forty years, several strategies and tools have been applied to optimize the management of public real estate with the purpose of increasing capital, saving costs and providing better services. The topic is still timely and relevant both at a national and at an international level. In Italy, the need to reduce and reallocate public spending [7] and to reprogram economic policies according to the European Fiscal Compact increased the relevance of public assets in Public Administrations' agendas [8]. More than a source of debt, public real estate started to be considered a source of revenue also at a local level [9], and the issue of its efficient and effective use became paramount. According to this approach, and in order to achieve these needs, many PAs - especially local ones-take advantage of their real estate portfolio to address the challenges of modern service delivery, applying new technologies and exploiting the opportunity to engage with the private sector [10].

According to these premises, public real estate enhancement requires the combination of public interest principles (intergenerational equity, social sustainability, effectiveness, accountability, etc.), key procedures of real estate management (public-private partnership, leasing, etc.) and other operational aspects (evaluation, performance evaluation, inventory, property maintenance, etc.), thus entailing a combination of the requirements of the managerial and of the political sphere. These requirements are often opposite (e.g., on one hand, the managerial processes require a long period of implementation to obtain results while, on the other hand, the political sphere requires results to be achieved in the short term).

Generally, the complexity of public real estate enhancement procedures derives from the need to balance the diversified interests involved, including the ones of the state, stakeholders, and final users [3], and from the need to combine procedural characteristics of the political/public and managerial spheres [11,12]. It is specifically in this "translation" that public real estate enhancement procedures have multiple issues, and this is the reason why benefits from public real estate enhancement occur extensively only in the short term, while a long-term view is desirable $[13,14]$.

Researchers and practitioners provided a rhapsodic view on public real estate enhancement and lack deep systematization of the methods and tools available for public property enhancement $[13,15,16]$. Namely, scientific contributions provided the cultural basis, the vision and the peculiarities of the management of public real estate, and highlighted the differences in objectives with CREM but, to date, there are still few contributions that support PAs in the decision-making process of enhancement, integrating economic, ethical and sustainable criteria $[17,18]$. There are, in fact, three main problems that PAs sill have to face: first, the complex system of financial and contractual tools for public real estate enhancement usually make the processes long and negotiation among actors difficult, given the lack of a mid/long-term strategic vision. Second, there is an overall lack of technical and managerial skills among PA staff for recognizing, distinguishing, deciding, and implementing these strategies. Third, there is a general poor knowledge of the existing portfolio, Gibson, 1994 [19].

The Italian context represents a privileged scenario for discussion, given the relevance of its public real estate both in terms of general quality and of consistency [20-22]. According to the latest report from the Italian national institute of statistics on non-financial wealth 
in Italy [23], the value of PAs' properties amounts to a total of about 346 billion euros (2017 data), of which 250 billion are related to non-residential properties, 86 billion to housing and 10 billion to cultivated land. As other research confirms, these data make the Italian State the most important operator in the real estate market in Italy (at least potentially [8]), so present and future research is required to provide definitive support to this real estate operator.

In Italy, the "enhancement" concept includes the functional use of the property according to the "direct or indirect benefit of the represented community" (article 2, legislative decree no. 85/2010), the ability of the property to generate income, and the possibility of being the object of investment policies at a territorial level [24]. According to the article 3 of the legislative decree no. 351/2001 [25], the Italian State Property Agency (Agenzia del Demanio) should promote processes of public real estate enhancement "consistent with the guidelines for territorial development" and should represent-within the economic and social context of reference- " an element of stimulus and attraction of local development interventions". Furthermore, "each public body shall ensure that the community is informed about the enhancement process" [26]. Thus, the reference law framework recognizes public buildings as assets that can positively contribute to the financial and social development of PAs and territories [8]. However, how can public administrations truly take advantage of this definition? What balance exists between the diversified requirements, needs, and expectations of the multiple actors involved?

This paper aims to critically systematize the methods and tools of public property enhancement that are currently available in Italy, suggesting a framework of criteria to support the decision-making process of Pas when enhancing their properties. The results of this paper derive from a path of research and dialogue on public real estate management, enhancement and regeneration between universities, and both public and private institutions in the Italian and international scenario involved in public real estate management, enhancement and regeneration.

\section{Approach and Methods}

The paper critically reflects on consolidated and innovative public real estate enhancement processes, applying an inductive approach. This paper uses the authors' experiences as researchers and practitioners engaged in public real estate enhancement and management in the Italian context, and an overview of the literature and of reference laws on public real estate enhancement processes constitutes the research framework. Namely, this research is built upon round tables, focus groups and fieldworks within the NAZCA group (composed of Politecnico di Milano, AUDIS - association of abandoned urban areas, and several Italian municipalities) [27], results of the ten-year research activity within OPPAL observatory on the local public administration's assets [28], and collaborative activities with the Italian State Property Agency (Agenzia del Demanio).

This viewpoint is the result of an articulated and cross-disciplinary research path assuming that the process of public real estate enhancement must be oriented towards public utility. Roundtables and meetings with PAs and real estate developers confirmed that, for years, enhancement strategies have been focused on the supply side (i.e., the amount of assets to enhance and their material/technical knowledge), while the demand side (i.e., expectations and needs of the different communities) was under-considered. This, instead, should play a pivotal role in the definition of the strategy, although a general difficulty emerges in the selection of the best enhancement strategy to apply. A critical approach towards public real estate enhancement is needed, since strategies are often selected by convenience, while a coherent approach towards strategy selection is desirable, considering that public real estate should maintain its public nature and must be oriented towards public utility. Therefore, is it possible to identify a system of criteria to support the decision-making process of the public entity in the selection of enhancement strategies that can pursue public utility? Which are the strategies that can build a balance between economic, technical and community requirements? The aim of this research is to build a 
practical approach for public real estate enhancement, according to a set of common criteria. This research is presented as a harshly focused rather than comprehensive viewpoint. This viewpoint does not have the ambition to holistically grasp public real estate enhancement processes and strategies in Italy but wants to practically address the issues that PAs are likely to have in selecting the best approach to public real estate enhancement and to provide them with support.

This research builds, according to the sources analyzed and the practical experience of the authors (especially of the author involved in the Italian State Property Agency), a taxonomy of criteria for the qualitative assessment of the public real estate enhancement strategies available in Italy and applies these criteria to the financial and contractual strategies for public real estate enhancement (both traditional and innovative).

This qualitative approach lacks robustness but attempts to be practically relevant. The qualitative assessment proposed in the following paragraphs is far from proposing a "one-size fits all" approach because the variety of strategies and of real estate portfolios does not allow unification. Instead, each PA-affecting different territorial level—is likely to operate in a different way and the criteria proposed do not allow comparability between enhancement strategies because each one has different procedures, objectives, timing, and partners involved.

This viewpoint has three sections. The first presents, and fully describes, the taxonomy of criteria designed, how criteria have been categorized according to the Italian regulatory framework and what their relevance is. As will be explained in the following paragraphs, given the strongly regulated Italian approach towards public real estate enhancement and the complexity of applying each strategy, the reference criteria mainly derive from laws because the literature often suffers from country specificities or subjective perspectives. The second section qualitatively proposes a critical assessment of the whole set of methods and tools for public real estate enhancement according to the taxonomy of criteria, by proposing synthetic tables of analysis for each tool. The last section discusses and concludes the viewpoint, suggesting future research developments.

\section{Definition of a Taxonomy of Criteria}

The taxonomy of criteria serves as a support for the decision-making process of PAs. Authors built the taxonomy according to the literature and Italian regulations on public real estate enhancement. According to a simplification and systematization procedure, two macro-categories of criteria make up the taxonomy: (i) "endogenous criteria" and (ii) "criteria of purpose".

Among the "endogenous criteria", this research recognizes all the rigid features of the public real estate enhancement tools that derive from the strict normative functioning of each method (i.e., type of property; time required; number of actors required; sharing the risk of the operation). These criteria must be deeply considered by PAs because they can immediately provide in/out evidence. Indeed, sources for each criterion generally derive from laws because the Italian context is highly regulated; the boundaries of the decision-making "power" of the PA cannot, in any case, be outside the prescriptive context, and PA is supposed to act transparently and to publicly account its procedure according to the law.

Among the "criteria of purpose" of the process, this research considers the variables of economy, efficiency, and effectiveness according to the seminal 3E model [29,30]. These are critical variables of a result-oriented system [31-33] and are likely to influence citizens' satisfaction [34]. These criteria derived from the discipline of New Public Governance (NPG) that gave birth to the concept of a horizontal relationship of participatory nodes and encouraged the emergence of new subjects alongside the classical decision-making process [35,36].

Table 1 summarizes the taxonomy of the proposed criteria. Each criterion has subcriteria when necessary, qualitative metrics of evaluation derived from the literature and normative reference sources, and-for clarity-each criterion refers to a related question. 
Table 1. Summary of the qualitative criteria for public real estate enhancement tools assessment. Authors' elaboration.

\begin{tabular}{|c|c|c|c|c|}
\hline Criteria & Sub-Criteria & Related Question & Metrics & Sources \\
\hline \multicolumn{5}{|l|}{ Endogenous Criteria } \\
\hline \multirow{6}{*}{ Type of property } & \multirow{3}{*}{$\begin{array}{l}\text { Minimum size of the assets' } \\
\text { portfolio }\end{array}$} & \multirow{3}{*}{$\begin{array}{l}\text { Which is the minimum } \\
\text { dimensional scale to activate } \\
\text { the strategy? }\end{array}$} & High (>20 millionn EUR) & \multirow{3}{*}[37]{} \\
\hline & & & $\begin{array}{c}\text { Medium }(1<x<20 \text { million } \\
\text { EUR })\end{array}$ & \\
\hline & & & Low (<1 million EUR) & \\
\hline & Asset's use & $\begin{array}{l}\text { Are the public buildings } \\
\text { used? }\end{array}$ & Used/Underused/Not used & {$[38,39]$} \\
\hline & $\begin{array}{l}\text { Profitability of the assets' } \\
\text { destination of use }\end{array}$ & $\begin{array}{l}\text { Does the public assets } \\
\text { provide profit for their } \\
\text { functions? }\end{array}$ & Hot/warm/cold & {$[25,38]$} \\
\hline & $\begin{array}{l}\text { Presence of planning } \\
\text { constraints }\end{array}$ & $\begin{array}{c}\text { In which state of conservation } \\
\text { is/are the asset/s? Does/do } \\
\text { the asset/s have an identity } \\
\text { value for people? }\end{array}$ & High/medium/low & [38-40] \\
\hline \multirow{3}{*}{$\begin{array}{l}\text { Time required for } \\
\text { activation }\end{array}$} & \multirow{3}{*}{-} & \multirow{3}{*}{$\begin{array}{l}\text { How much time is available } \\
\text { or required for assets' } \\
\text { enhancement? }\end{array}$} & High (>1 year) & \multirow{3}{*}{$\begin{array}{l}\text { Strict functioning of the process } \\
\text { expressed by law, empirical research } \\
\text { and }[38,40]\end{array}$} \\
\hline & & & $\operatorname{Medium}(6 \mathrm{~m}<\mathrm{x}<1 \mathrm{y})$ & \\
\hline & & & Low (<6 months) & \\
\hline \multirow{3}{*}{$\begin{array}{l}\text { Number of actors to be } \\
\text { involved }\end{array}$} & \multirow{3}{*}{-} & \multirow{3}{*}{$\begin{array}{l}\text { How many actors are needed } \\
\text { to activate the process? }\end{array}$} & High ( $>4$ actors) & \multirow{3}{*}{$\begin{array}{l}\text { Strict functioning of the process } \\
\text { expressed by law [41], empirical } \\
\text { research }\end{array}$} \\
\hline & & & Medium $(3<\mathrm{x}<4$ actors) & \\
\hline & & & Low (2 actors) & \\
\hline \multirow{2}{*}{ Sharing of the risk } & \multirow{2}{*}{-} & \multirow{2}{*}{$\begin{array}{l}\text { Are the risks of the operation } \\
\text { shared between actors? }\end{array}$} & Shared & \multirow{2}{*}{$\begin{array}{l}\text { Strict functioning of the process } \\
\text { expressed by law, empirical research } \\
\text { and }[25,38,42]\end{array}$} \\
\hline & & & Not shared & \\
\hline \multicolumn{5}{|l|}{ Criteria of Purpose } \\
\hline Economy & - & $\begin{array}{c}\text { Does the process have a high } \\
\text { impact on the balance sheet of } \\
\text { the PA? }\end{array}$ & Max price $(€)$ & {$[29,30,43]$} \\
\hline Efficiency & - & $\begin{array}{l}\text { Does the process maximize } \\
\text { the economic benefit with } \\
\text { respect to the resources used? }\end{array}$ & Max (output/input) & {$[29,30]$} \\
\hline Effectiveness & - & $\begin{array}{l}\text { Do the benefits (included } \\
\text { social ones) outweigh the } \\
\text { costs of the process? }\end{array}$ & Cost/benefit & {$[29,30]$} \\
\hline
\end{tabular}

\subsection{Endogenous Criteria}

\subsubsection{Type of Property}

The criterion of "type of property" considers the following sub-criteria, strongly connected to the material features of the real estate-minimum dimensional scale; use and profitability of assets; presence of planning and urban constraints:

- Minimum dimensional scale: some strategies, such as the real estate fund, require a minimum dimensional scale (expressed as the value in euros) for their activation. Other enhancement tools entail structural costs that make the operation convenient only when the assets exceed a certain size threshold [37]. In this research, this benchmark value corresponds to 20 million euros that derive from the minimum endowment of a local fund (the critical mass consistent with the complexity/costs of the fund);

- Use and profitability of the asset: some enhancement tools work on the transformation of the value of properties (e.g., through maintenance activities) and others work on the ability of properties to generate profit (e.g., through rent fees). According to these diversifications, the "type of property" criterion considers two different sub-criteria: asset's use (used, unused or under-used); asset's profitability (ability to generate profit). Tools such as securitization or urban transformation companies (STU) work primarily on transforming the value of real estate. Project finance and real estate funds are solutions suitable for profitable properties as derived from their structuring laws [38,39]. Asset management companies can adapt well to both types of assets [38];

- Presence of planning constraints: Pas cannot dispose assets constrained by a cultural or an identity value (see articles 53-57-bis, legislative decree no. 42/2004 "Alienation and 
other modes of transmission"), while in some cases, the restriction on the destination of use is likely to advise the most favorable strategy [38].

\subsubsection{Time Required for the Enhancement Process}

The time needed both to obtain the necessary resources and to activate and implement the enhancement strategy represents a critical variable (i.e., impacts time availability of PAs). This criterion considers the procedural time necessary for placing the asset on the market in compliance with the principles of non-discrimination, mutual recognition, transparency and cost-effectiveness (i.e., procedures of public evidence) or aimed at finalizing administrative actions prodromal to the enhancement (e.g., changes of use, checks of the cultural interest of the asset). Each solution has its specific time requirements according to law, e.g., [40]. It should be noted, however, that for some solutions, such as securitization and real estate funds, which take a long time to complete, it is possible to combine bridge loans that anticipate the results [38].

\subsubsection{Number of Actors Required for the Enhancement Process}

The number of actors-public or private-involved in the enhancement process drastically increases the procedural complexity. Moreover, the involvement of private partners with qualified specialist resources can facilitate strategies' implementation, but also hamper it due to negotiation difficulties. The number of actors depends on the strict functioning of the procedure.

\subsubsection{Sharing of the Risk of the Enhancement Process}

The risk variable can be charged to one or more of the actors involved in the process. The risk influences the attractiveness of private investments in the construction and management of works or in the supply of services, and it depends on the type of contract that the administration intends to develop. The risk, therefore, can be either equally distributed between the parties or fall on only one [42], articles 3 and 180. For example, a Public-Private Partnership (PPP) contract allocates to the private operator: (a) the operational risk (i.e., the risk associated with the management of works or services and related to the demand side, or the supply side, or both); (b) the construction risk (i.e., the risk linked to the delay in delivery times, non-compliance with project standards, increased costs, technical inconveniences or failure to complete the work); (c) the availability risk (i.e., the risk linked to the ability to provide the agreed contractual services, both in terms of volume and quality standards); (d) in cases of profitable activity, also the demand risk (i.e., the risk related to different volumes of demand for the work/service.

\subsection{Criteria of Purpose}

\subsubsection{Economy}

When an enhancement process or a disposal operation is carried out, the PA usually has the objective of maximizing the sale price (or concession fee). Therefore, the economy variable is intended as the impact on the economic balance sheet of the PA $[29,30]$.

\subsubsection{Efficiency}

This research considers a strategy efficient when the economic well-being (alignment with the economy criterion) is maximized with respect to the use of input resources [29,30]. Input resources consider both the time necessary for the operation and the costs for the enhancement procedure (consultancy, administrative management, etc.).

\subsubsection{Effectiveness}

The effectiveness variable depends on the economic, social and environmental additionality intended as a benefit-cost ratio: the degree to which the benefits (tangible and intangible values) outweigh the costs and whether this is in line with PA's strategic objectives $[29,30]$. 


\section{Results: Qualitative Assessment of Public Real Estate Enhancement Methods and Tools}

The following paragraphs qualitatively assess public real estate enhancement methods, tools, and processes within the taxonomy of criteria proposed in this research. These criteria and the analysis reported in the tables below are likely to provide support to PAs in deciding which enhancement tool or method to use and manage, and to which aim. This research limits its scope by considering financial, contractual, and urban transformation tools and methods for real estate enhancement and, among these tools, the research considers both the mainstream and innovative ones that have been used and deemed as suitable by PAs for enhancement in the Italian context. The purpose of the analysis is to understand how these tools and methods meet-or not-the criteria proposed in this research, starting from the mainstream ones, then moving towards innovative ones (like those most recently introduced into the Italian regulatory framework).

\subsection{Securitization}

Securitization is a financial technique for assets' disposal, used to enable the conversion of publicly owned assets into financial instruments that are more easily marketable (securities). The procedure, given its complexity, requires large portfolios of assets and a long time, depending on the period required for the reimbursement of securities. In a securitization transaction, the owner (originator) transfers the ownership to a third party (usually called Special Purpose Vehicle (SPV)). These acquired assets guarantee the holders of the securities, the subjects granting the loans and any other creditor [43]. The main strength of the securitization process is the generation of an immediate cash flow [38]. Since the strategy is totally managed by third parts, the main weakness is that the PA does not acquire effective managerial competences in the process; nonetheless, the PA can intervene ex ante on the underused assets that will be included in the portfolio by changing their destination of use or their physical qualities. Securitization as a long-term process is, therefore, advisable only if the PA's strategy is to meet the criterion of economy, while the process seems to be efficient only at the end of the process itself and only if the management of the process is transparent and result-oriented from the beginning. Table 2 shows how the taxonomy of proposed criteria assesses the securitization process.

Table 2. Analysis of the securitization process. Authors' elaboration.

\begin{tabular}{|c|c|c|}
\hline Criteria & Metrics & Qualitative Assessment \\
\hline \multicolumn{3}{|l|}{ Endogenous Criteria } \\
\hline Dimensional scale & High & $\begin{array}{l}\text { The process requires high-dimension portfolios of } \\
\text { assets. }\end{array}$ \\
\hline Use & Used/Underused/Not used & $\begin{array}{l}\text { Securitization is used for underused assets with a } \\
\text { high potentiality to generate profit. }\end{array}$ \\
\hline Profitability of assets' destination of use & Cold & $\begin{array}{l}\text { Securitization works mainly on the transformation } \\
\text { of the value of the assets through the enhancement } \\
\text { and not on their initial profitability. }\end{array}$ \\
\hline Presence of planning constraints & Low & $\begin{array}{l}\text { The assets should have a low identity value and not } \\
\text { be under planning constraints. }\end{array}$ \\
\hline Time required & High & $\begin{array}{l}\text { The process requires years. It is possible to combine } \\
\text { bridge loans to anticipate the results of operation. }\end{array}$ \\
\hline Actors to be involved & High & $\begin{array}{l}\text { At least } 8 \text { different actors: originator; SPV; Bank; } \\
\text { Rating agencies; Credit enhancer; Investors; Sponsor; } \\
\text { Servicer. }\end{array}$ \\
\hline Sharing of the risk & Shared & $\begin{array}{l}\text { Shared among the actors. The risk is mainly given to } \\
\text { the originator and to the credit enhancer. }\end{array}$ \\
\hline
\end{tabular}


Table 2. Cont

\begin{tabular}{lll}
\hline \multicolumn{1}{c}{ Criteria } & \multicolumn{1}{c}{ Metrics } & \multicolumn{1}{c}{ Qualitative Assessment } \\
\hline Criteria of Purpose & Yes (max price) & $\begin{array}{l}\text { Since the securitization is used for large asset } \\
\text { portfolios; after the disposal there will be a high } \\
\text { positive impact on public finances. }\end{array}$ \\
\hline Efficiency & Yes (max output/input) & $\begin{array}{l}\text { The strategy is efficient only for large real estate } \\
\text { portfolios: the tool requires high structuring costs } \\
\text { and the involvement of many actors. }\end{array}$ \\
\hline Effectiveness & No (min cost/benefit) & $\begin{array}{l}\text { There is no warranty of effectiveness because the } \\
\text { management is given to the future buyer of the } \\
\text { assets. The guaranteed benefit for the PA is only in } \\
\text { economic terms. }\end{array}$ \\
\hline
\end{tabular}

\subsection{Leasing}

The leasing contract is a financing contract that permits the availability of an asset in exchange for the payment of a periodic rent. At the end of the contract, the asset can be sold to the user for an amount lower than the market value. Usually, the PA (the supplier) is likely to resort to a real estate leasing operation for the instrumental properties which it intends to maintain use of, transferring them to a leasing company (the lessor) which, in turn, would lease them to the PA itself or other private or public entities (the lessee). The main strength of a leasing contract is the transfer of risk to the leasing company that acquires the assets [44]. This tool is not widely used for public property enhancement, even if, according to the proposed taxonomy of criteria, the procedure can assure both efficiency (the procedure is based on the affordability and accountability of the parties) and the economy criteria (at least in the short term). Table 3 shows how the taxonomy of criteria proposed assesses the leasing tool.

Table 3. Analysis of the leasing tool. Authors' elaboration.

\begin{tabular}{|c|c|c|}
\hline Criteria & Metrics & Qualitative Assessment \\
\hline \multicolumn{3}{|l|}{ Endogenous Criteria } \\
\hline Dimensional scale & High/medium/low & There is not a limit in the dimensional scale. \\
\hline Use & Used/Underused/Not used & No specification. \\
\hline $\begin{array}{l}\text { Profitability of assets' destination } \\
\text { of use }\end{array}$ & Warm/Cold & $\begin{array}{l}\text { Leasing (in costruendo) is mainly used for worm and cold works: the } \\
\text { strategy is not based on the financial sustainability but works on the } \\
\text { transformation of the value of the assets. }\end{array}$ \\
\hline $\begin{array}{l}\text { Presence of planning } \\
\text { constraints/identity value }\end{array}$ & Low/medium/high & No specification. \\
\hline Time required & High & The minimum duration of the contract is 8 years. \\
\hline Actors to be involved & Medium & $\begin{array}{l}\text { The process involves at least } 4 \text { actors: PA; leasing company or lessor; } \\
\text { lessee (private or public entity). }\end{array}$ \\
\hline Sharing of the risk & Shared & The risk is transferred to the leasing company. \\
\hline \multicolumn{3}{|l|}{ Criteria of Purpose } \\
\hline Economy & Yes (max price) & $\begin{array}{l}\text { Positive impact in the short term: debt reduction on PA's balance sheet. } \\
\text { In the long term it will have to be evaluated based on the discounted } \\
\text { cash flow (DCF) of the transaction, taking into account the discounted } \\
\text { value of future fees and the mark up granted to the private investor. }\end{array}$ \\
\hline Efficiency & Yes (max output/input) & Possibility of a continuous monitoring and control by the PA. \\
\hline Effectiveness & No (min cost/benefit) & $\begin{array}{l}\text { Effectiveness is not warranted because this is not a often-used tool for } \\
\text { enhancement at least in Italy. }\end{array}$ \\
\hline
\end{tabular}




\subsection{Real Estate Fund}

Public assets included in a real estate fund can be managed directly by the PA, by specialized companies, or can be placed on the market to be sold. At the end of the fund's life, all the assets must be disposed, and the proceeds distributed to investors. The instrument needs a critical consistency for its activation related to the complexity and the cost of the fund [45].

In recent years, the public contribution real estate fund has been one of the most widely used tools for public real estate disposal in Italy, according to the legislative decree 98/2011 named "Urgent provisions for financial stabilization" [46]. For example, "Fondo Immobili Pubblici (FIP)" allowed the disposal of about 400 public properties, for a total amount of about 3 billion euros, and the "Patrimonio Uno" fund, through which about 1 billion euros of properties for non-residential use has been divested. The decision of a public authority to set up a fund comes from a long-term strategic vision: if the purpose of the PA is to sell assets at their maximum price (i.e., meet the criterion of economy), a real estate fund can meet this need, by setting the rules and characteristics of the fund at the beginning of the procedure and characteristics, according to the economic-financial needs and the available resources (properties). Furthermore, the complex governance structure of a real estate fund (corporate governance bodies, executive bodies, control bodies that include the PA) is likely to ensure the transparency, efficiency and effectiveness of the procedure. Table 4 shows the analysis of the real estate fund enhancement tool according to the taxonomy of the proposed criteria.

Table 4. Analysis of the real estate fund tool. Authors' elaboration.

\begin{tabular}{|c|c|c|}
\hline Criteria & Metrics & Qualitative Assessment \\
\hline \multicolumn{3}{|l|}{ Endogenous Criteria } \\
\hline Dimensional scale & High & $\begin{array}{l}\text { Legislative Decree } 267 / 2000 \text { provides a critical mass of about } \\
\text { EUR 20-30 million [37]. }\end{array}$ \\
\hline Use & Used/Underused/Not used & Usually used/unused assets. \\
\hline $\begin{array}{l}\text { Profitability of assets' } \\
\text { destination of use }\end{array}$ & Worm/hot & $\begin{array}{l}\text { Real estate fund works for assets that provide profit. } \\
\text { Differently, the assets should undergo renovation works. }\end{array}$ \\
\hline $\begin{array}{l}\text { Presence of planning } \\
\text { constraints/identity value }\end{array}$ & Low & $\begin{array}{l}\text { No specification but, since it is a strategy of disposal, a low } \\
\text { identity value is expected. }\end{array}$ \\
\hline Time required & High & $\begin{array}{l}\text { The maximum duration of the fund is } 30 \text { years. It is possible } \\
\text { to combine bridge loans that anticipate the results of } \\
\text { operation. }\end{array}$ \\
\hline Actors to be involved & High & $\begin{array}{l}\text { High number of actors: asset management company (SGR); } \\
\text { bank; PA; Investors; corporate governance body. }\end{array}$ \\
\hline Sharing of the risk & Shared & Shared between PA and investors. \\
\hline \multicolumn{3}{|l|}{ Criteria of Purpose } \\
\hline Economy & Yes (max price) & $\begin{array}{l}\text { High economic impacts because of the high number of assets } \\
\text { in the portfolio of a real estate fund. PA can receive liquidity } \\
\text { from the distribution of the shares and in the distribution of } \\
\text { the plus value at the end of fund's life or from the direct } \\
\text { disposal to the fund. }\end{array}$ \\
\hline Efficiency & Yes (max output/input) & $\begin{array}{l}\text { High efficiency. The SGR is expected to have property and } \\
\text { facility management competences. The high building costs of } \\
\text { the strategy are supposed to be repaid. }\end{array}$ \\
\hline Effectiveness & Yes (max cost/benefit) & $\begin{array}{l}\text { A real estate fund can be built with different partners and } \\
\text { actors, as a warranty of social benefits-i.e., integrated system } \\
\text { of funds for social housing [47]. The contribution of assets to a } \\
\text { real estate fund appears potentially suitable also for the } \\
\text { implementation of place development, infrastructure works } \\
\text { or social project. }\end{array}$ \\
\hline
\end{tabular}




\subsection{Concession, Enhancement Concession and Project Finance}

Concession, through project financing (PF), represents a tool partially used by PAs for public real estate enhancement. Concession is an enhancement tool of contractual type whose duration must be fixed in a time frame that enables cost refund and profit achievement [43]. The PF technique [48] is a financial tool used to identify a private entity that not only performs a work but actively cooperates with PA in identifying the characteristics of the activity or the service that the asset will provide. The private partner receives remuneration for the activities and provides a fee for assets' use to the PA. At the end of the concession period, the assets return to the full availability of the PA. In Italy, with the term "concession", we can distinguish between:

- Ordinary concession/lease often used for the income generation from public real estate enhancement (ex D.P.R. 13 September 2005, n. 296); this has a duration of 6 years with a maximum extension of 19 years;

- Concession of enhancement used for projects enhancing public assets with respect to private use-e.g., tourism (art. 3-bis D.L. no. 351/2011 converted into law, with amendments, by art. 1, Law no. 410/2001);

- Concession under the code of public procurement contracts (Legislative Decree 50/2016), which is instead less used for purposes of real estate enhancement, but rather for the provision of public services or public utilities.

Table 5 shows the qualitative assessment of the concession processes.

Table 5. Analysis of the concession tool. Authors' elaboration.

\begin{tabular}{|c|c|c|}
\hline Criteria & Metrics & Qualitative Assessment \\
\hline \multicolumn{3}{|l|}{ Endogenous Criteria } \\
\hline Dimensional scale & Low & $\begin{array}{l}\text { There is not a dimensional limit. The concession is used mainly for } \\
\text { single assets. }\end{array}$ \\
\hline Use & Used/Underused/Unused & $\begin{array}{l}\text { Mainly for underused or unused assets. The concession often } \\
\text { provides, at least in part, a change in the destination of use. }\end{array}$ \\
\hline $\begin{array}{l}\text { Profitability of assets' } \\
\text { destination of use }\end{array}$ & Worm/hot & $\begin{array}{l}\text { Usually, this tool works on the ability of properties to generate } \\
\text { profit. Moreover, concession free of charge works well for no-profit } \\
\text { activities. }\end{array}$ \\
\hline $\begin{array}{l}\text { Presence of planning } \\
\text { constraints/identity value }\end{array}$ & - & $\begin{array}{l}\text { Not specified. Only in enhancement concession (concessione di } \\
\text { valorizzazione) the identity value of the building is usually high, and } \\
\text { mainly motivate the project. }\end{array}$ \\
\hline Time required & High & $\begin{array}{l}\text { The longer it lasts, the more easily the project is profitable (the } \\
\text { concession of enhancement as well as the ordinary concession has a } \\
\text { maximum duration of } 50 \text { years.). }\end{array}$ \\
\hline Actors to be involved & High & $\begin{array}{l}\text { Stakeholders; PA; eventual special purpose vehicle (SPV); banks (as } \\
\text { sponsors); concessionaire (private part), final users of the asset. }\end{array}$ \\
\hline Sharing of the risk & Shared & $\begin{array}{l}\text { The risk is shared between public and private partners. With PF } \\
\text { technique, the operational risk is in the hand of the concessionaire, } \\
\text { together with almost two of the following types of risk: } \\
\text { construction, availability, and demand risks. }\end{array}$ \\
\hline \multicolumn{3}{|l|}{ Criteria of Purpose } \\
\hline Economy & Yes (max price) & Economic impact both for public and private part. \\
\hline Efficiency & Yes (max output/input) & $\begin{array}{l}\text { The public and private parts jointly evaluate the technical project } \\
\text { and the design idea, cooperate in selection, management, and } \\
\text { control of the activities / services that the public assets will offer } \\
\text { during the concession contract. }\end{array}$ \\
\hline Effectiveness & Yes (max cost/benefit) & $\begin{array}{l}\text { As a strategy of PPP, the concession implies an adequate demand of } \\
\text { service to be maintained and monitored during time. If this } \\
\text { demand exists, the effectiveness is warranted. }\end{array}$ \\
\hline
\end{tabular}




\subsection{Asset Company}

The Italian legal system $[49,50]$ allows public authorities to set up special joint-stock companies, to which PA entrusts the task of holding, managing and enhancing their own assets. In particular, the establishment of this entity provides the transfer of a real estate portfolio to a newly established company whose share capital can be totally controlled by the public entity or open to private shareholders. In the latter case, it is referred to as a joint enterprise (public-private). In both cases, the purpose of the company is reported in its business plan. Depending on the strategy reported in this plan, the asset company tool can be evaluated as effective or not. In general, asset companies focus their activities on property management, to maintain the value of the buildings, or on asset management, to consider public real estates as drivers of development for the territory. Indeed, asset companies meet the need of economy and efficiency, especially when shared with a thirdparty operator. Table 6 shows the qualitative assessment results of the asset company tool according to the taxonomy of criteria proposed in this research.

Table 6. Analysis of the asset company. Authors' elaboration.

\begin{tabular}{|c|c|c|}
\hline Criteria & Metrics & Qualitative Assessment \\
\hline \multicolumn{3}{|l|}{ Endogenous Criteria } \\
\hline Dimensional scale & Low/medium/high & No specification. \\
\hline Use & Used/Underused/Unused & Mainly for underused or unused assets. \\
\hline $\begin{array}{l}\text { Profitability of assets' } \\
\text { destination of use }\end{array}$ & Worm/hot & $\begin{array}{l}\text { The strategy is based on improving the economic value of } \\
\text { the assets with profitable activities or thorough maintenance } \\
\text { activities. }\end{array}$ \\
\hline $\begin{array}{l}\text { Presence of planning } \\
\text { constraints/identity value }\end{array}$ & Medium identity value & $\begin{array}{l}\text { Mainly for underused or unused assets that need to be } \\
\text { valorized. }\end{array}$ \\
\hline Time required & Low/medium/high & $\begin{array}{l}\text { No specification. Depends on the number of assets to be } \\
\text { managed and on the success of activities }\end{array}$ \\
\hline Actors to be involved & Medium & Public body; Private partner; Asset company; Banks. \\
\hline Sharing of the risk & Shared & Between private and public part. \\
\hline \multicolumn{3}{|l|}{ Criteria of Purpose } \\
\hline Economy & Yes (max price) & $\begin{array}{l}\text { Positive impact on the balance sheet of the PA (proceeds } \\
\text { from rents or sales). }\end{array}$ \\
\hline Efficiency & Yes (max output/input) & Optimization of management costs. \\
\hline Effectiveness & No (min cost/benefit) & $\begin{array}{l}\text { Difficulty in aligning different interests. Need for a property } \\
\text { management third part. Risk of low transparency in the } \\
\text { asset management process. }\end{array}$ \\
\hline
\end{tabular}

\subsection{Urban Transformation Company}

The Urban Transformation Companies-commonly known with the Italian acronym STU for Società di Trasformazione Urbana [51] - are corporate bodies build by public and private subjects to jointly operate on areas or on real estate complexes. The STU can be defined as a purpose company since it is formed only to achieve a specific goal and will be dissolved after the achievement of these objectives. This public-private management tool has remained mainly underused in Italy [52]. Entrepreneurial subjects, able to provide financial resources and managerial skills, are involved in the management of the procedure: the main strength lies in the opportunity to use private financial resources for public aims. PAs have a controlling role in the process. Table 7 shows how the STU has been assessed thanks to the criteria proposed in this research. The tool requires a pre-feasibility analysis; thus, the implementation procedure is complex. An STU is characterized by high fixed costs at the beginning of the procedure, while revenues are expected only at the end. Complexity 
also derives from the possible misalignment of visions between the public and the private actors involved.

Table 7. Analysis of the Urban Transformation Company. Authors' elaboration.

\begin{tabular}{|c|c|c|}
\hline Criteria & Metrics & Qualitative Assessment \\
\hline \multicolumn{3}{|l|}{ Endogenous Criteria } \\
\hline Dimensional scale & High & $\begin{array}{l}\text { It is used for the enhancement of the city's area/building } \\
\text { complexes. }\end{array}$ \\
\hline Use & Underused/Not used & $\begin{array}{l}\text { Usually used for the enhancement of underused or abandoned } \\
\text { areas. }\end{array}$ \\
\hline $\begin{array}{l}\text { Profitability of assets' } \\
\text { destination of use }\end{array}$ & Cold/Worm/hot & $\begin{array}{l}\text { The strategy in the long run should provide direct or indirect } \\
\text { profit. The strategy works primarily on transforming the value } \\
\text { of the assets. }\end{array}$ \\
\hline $\begin{array}{l}\text { Presence of planning } \\
\text { constraints/identity value }\end{array}$ & - & $\begin{array}{l}\text { It is possible that high identity value justifies the project. The } \\
\text { same happens with urban regeneration projects. }\end{array}$ \\
\hline Time required & High & The positive effects of a STU start in the long time. \\
\hline Actors to be involved & Medium & $\begin{array}{l}\text { Public partner (user), Public partner (promoter); private partner } \\
\text { (user); Investors. }\end{array}$ \\
\hline Sharing of the risk & Shared & Shared in the different phases of the process. \\
\hline \multicolumn{3}{|l|}{ Criteria of Purpose } \\
\hline Economy & Yes (max price) & $\begin{array}{l}\text { The revenues are not guaranteed and will start at the end of the } \\
\text { process. The PA has only to provide the assets without any } \\
\text { financial outlay. }\end{array}$ \\
\hline Efficiency & Yes (max output/input) & $\begin{array}{l}\text { Depends on the type of project, from capital sharing and from } \\
\text { the type of private actor/developer involved. }\end{array}$ \\
\hline Effectiveness & Yes (max cost/benefit) & $\begin{array}{l}\text { Italian experiences did not show the expected results. High risk } \\
\text { of misalignment of mission/vision between the different } \\
\text { subjects. }\end{array}$ \\
\hline
\end{tabular}

\subsection{Real Estate Investment Trusts (REITs)}

The 2007 Finance Law introduced a new category of corporate vehicles in Italy: Real Estate Investment Trusts (known in Italy with the acronym SIIQ for Società di investimento immobiliare quotata) [53]. The main benefit of these vehicles istheir particular tax neutrality/transparency regime. This condition is assured as long as the company (i) has the legal form of a joint-stock company; (ii) reside in the Italian territory; (iii) has real estate leasing as a prevalent activity (at least $80 \%$ ); (iv) is listed on an Italian regulated market; (v) distributes of at least $85 \%$ of the net profit deriving from the real estate rental activity to shareholders. This type of strategy is not usually used for public asset enhancement, except for very profitable operations, given the predominance of rental activities, the high dimension portfolio of assets required, and time. Table 8 shows how REITs have been assessed thanks to the criteria proposed in this research. 
Table 8. Analysis of the Real estate investment trust (REITs) tool. Authors' elaboration.

\begin{tabular}{|c|c|c|}
\hline Criteria & Metrics & Qualitative Assessment \\
\hline \multicolumn{3}{|l|}{ Endogenous Criteria } \\
\hline Dimensional scale & High & High dimensional scale to justify the listing on the market. \\
\hline Use & Used & Used with activities that provide profit. \\
\hline $\begin{array}{l}\text { Profitability of assets' } \\
\text { destination of use }\end{array}$ & Worm/hot & $\begin{array}{l}\text { Yes, to justify listing on the stock exchange and the mandatory } \\
\text { predominance of rental activities. }\end{array}$ \\
\hline $\begin{array}{l}\text { Presence of planning } \\
\text { constraints/identity value }\end{array}$ & Medium/Low & $\begin{array}{l}\text { Good maintenance state but low identity value because the assets } \\
\text { are practically sold to the company. }\end{array}$ \\
\hline Time required & High & High, to provide shareholder return of the investment. \\
\hline Actors to be involved & High & $\begin{array}{l}\text { Possibility to start synergic actions with other public } \\
\text { administrations to have higher amount of assets in the portfolio. }\end{array}$ \\
\hline Sharing of the risk & Shared & Shared between PA and Investors. \\
\hline \multicolumn{3}{|l|}{ Criteria of Purpose } \\
\hline Economy & Yes (max price) & $\begin{array}{l}\text { The tool implies fiscal benefits and a high impact on the balance } \\
\text { sheet of the PA because of the high market value of the buildings to } \\
\text { be valorized (Profit test). }\end{array}$ \\
\hline Efficiency & Yes (max output/input) & $\begin{array}{l}\text { Efficient, because real estate management is the core business of the } \\
\text { REIT company. High risk within the process because of the } \\
\text { volatility of Italian stock exchange for the discount of shares. }\end{array}$ \\
\hline Effectiveness & No (min cost/benefit) & $\begin{array}{l}\text { Effectiveness is not warranted because this tool is an alienation } \\
\text { strategy aimed at making profit from buildings yet rented with no } \\
\text { control on the social-economic and environmental impacts. This } \\
\text { tool is not commonly used for public buildings' enhancement, even } \\
\text { if it can represent an opportunity strategy with adjustments. }\end{array}$ \\
\hline
\end{tabular}

\subsection{Trust}

The trust is a legal institute able to create a fiduciary relationship between a public entity, called the "settlor", and a second entity, called the "trustee", who become the managers of the assets. The settlor (the PA) obtains the revenues from the trustee with respect to the settlor's restrictions on the use of the income generated from the asset. Thus, public aims can be reached thanks to private resources. Table 9 shows how trust has been assessed thanks to the criteria proposed in this research.

Table 9. Analysis of the Trust method. Authors' elaboration.

\begin{tabular}{lll}
\hline \multicolumn{1}{c}{ Criteria } & \multicolumn{1}{c}{ Metrics } & Qualitative Assessment \\
\hline Endogenous Criteria & High/medium/low & No specification. \\
\hline Dimensional scale & Used/Underused/Not used & No specification. \\
\hline Use & Cold/warm & Usually is used for cold and worm works. \\
\hline $\begin{array}{l}\text { Profitability of assets' } \\
\text { destination of use }\end{array}$ & Low/medium/High & No specification. \\
\hline $\begin{array}{l}\text { Presence of planning } \\
\text { constraints/identity value }\end{array}$ & Medium & $\begin{array}{l}\text { Trust speed up the time necessary to complete the work thanks } \\
\text { to the outsourcing of certain tasks to qualified entities. }\end{array}$ \\
\hline \begin{tabular}{l} 
Time required \\
\hline
\end{tabular} & &
\end{tabular}


Table 9. Cont.

\begin{tabular}{lll}
\hline \multicolumn{1}{c}{ Criteria } & \multicolumn{1}{c}{ Metrics } & \multicolumn{1}{c}{ Qualitative Assessment } \\
\hline Endogenous Criteria & Medium & Settlor (PA); Trustee (third part); Beneficiary (PA). \\
\hline Actors to be involved & Not shared & The trustee manages the risk. \\
\hline Sharing of the risk & Yes (max price) & Yes, if the PA is not only the settlor but also the beneficiary. \\
\hline Criteria of Purpose & Yes (max output/input) & $\begin{array}{l}\text { Yes, both because of the supervision and control of the PA and } \\
\text { for the management of qualified entities. }\end{array}$ \\
\hline Economy & Yes (max cost/benefit) & Yes, if the programs of the PA and of the trustee are aligned \\
\hline Efficiency &
\end{tabular}

\subsection{Availability Contract}

The availability contract is a public-private partnership contract by which a privately owned asset is envisioned for the provision of services (usually of public interest) for a fee [54]. The ownership, therefore, belongs to the private party from the beginning which assumes the economic risks of construction and technical management of the property. The availability contract specifies that the public entity pays the availability fee only "in proportion to the actual availability of the work" and that it shall be "proportionately reduced or cancelled during periods of reduced or no availability of the work" [55]. Even if no specification is given about the dimensional scale necessary to activate the strategy, this is used for single-asset enhancement. Table 10 presents the availability contract tool's analysis.

Table 10. Analysis of the Availability contract tool. Authors' elaboration.

\begin{tabular}{|c|c|c|}
\hline Criteria & Metrics & Qualitative Assessment \\
\hline \multicolumn{3}{|l|}{ Endogenous Criteria } \\
\hline Dimensional scale & High/medium/low & No specification. \\
\hline Use & Used/Underused/Not used & $\begin{array}{l}\text { Usually it concerns assets used or underused or not currently used but } \\
\text { to be re-functionalized for their future use in the public interest (public } \\
\text { offices, archives, social infrastructure, etc.). }\end{array}$ \\
\hline $\begin{array}{l}\text { Profitability of assets' destination of } \\
\text { use }\end{array}$ & Cold/worm/Hot & No specification. \\
\hline $\begin{array}{l}\text { Presence of planning } \\
\text { constraints/identity value }\end{array}$ & Low & Mainly for implementation and new construction. \\
\hline Time required & High & Between 10 and 30 years. \\
\hline Actors to be involved & Medium & Public Body; Banks; Public service work body; Management body; SPV. \\
\hline Sharing of the risk & Shared & $\begin{array}{l}\text { Construction and availability risks are allocated to private part while } \\
\text { the demand risk is in the hand of the public part that firstly design the } \\
\text { process. }\end{array}$ \\
\hline \multicolumn{3}{|l|}{ Criteria of Purpose } \\
\hline Economy & No (min price) & $\begin{array}{l}\text { The PA pays only a periodic fee to the private part for the availability of } \\
\text { the service. The contract includes the hypothesis of purchasing the asset } \\
\text { at the end. }\end{array}$ \\
\hline Efficiency & Yes (min output/input) & $\begin{array}{l}\text { The economic resources and managerial skills mainly weighs on the } \\
\text { private part that also represents the beneficiary of the operation. } \\
\text { Efficiency depends on the type of project and from the type of private } \\
\text { actor involved. }\end{array}$ \\
\hline Effectiveness & Yes (max cost/benefit) & $\begin{array}{l}\text { PA has low costs but can exploit the benefits if there is a share in the } \\
\text { mission with the private part. }\end{array}$ \\
\hline
\end{tabular}




\subsection{Sponsorship}

Sponsorships acquired importance especially for real estates characterized by a strong cultural value (i.e., cultural heritage). In a sponsorship contract, PA is mainly a sponsored passive actor (sponsee), while private subjects are active actors (sponsor) [41,56]. The sponsee agrees, for a fee, to allow behavior that gives the sponsor the opportunity to exploit the authority and reputation of the sponsee, in order to achieve the growth of the private sponsor's knowledge among the community. The PA obtains an indirect form of financing, which can be used for public asset maintenance or, in a sponsorship of a technical nature, for services, works and goods supply [57]. Table 11 shows the analysis of the sponsorship enhancement tool. The analysis shows a generally poor rate of the tool according to the criteria of purpose presented in this research.

Table 11. Analysis of the Sponsorship tool. Authors' elaboration.

\begin{tabular}{lll}
\hline \multicolumn{1}{c}{ Criteria } & \multicolumn{1}{c}{ Metrics } & \multicolumn{1}{c}{ Qualitative Assessment } \\
\hline Endogenous Criteria & Low & No specification, but mainly used for single assets. \\
\hline Dimensional scale & Used/Underused/Not used & No specification. Mainly used for used assets. \\
\hline Use & Cold/worm & $\begin{array}{l}\text { The strategy works on the transformation of assets value in } \\
\text { terms of quality and not in terms of profitability. }\end{array}$ \\
\hline $\begin{array}{l}\text { Profitability of assets' } \\
\text { destination of use }\end{array}$ & High & Used mainly for public cultural heritage. \\
\hline $\begin{array}{l}\text { Presence of planning } \\
\text { constraints/identity value }\end{array}$ & Low/medium/high & No specification. \\
\hline $\begin{array}{l}\text { Time required } \\
\text { Actors to be involved }\end{array}$ & Low & At least two actors: sponsor and sponsee (PA). \\
\hline Sharing of the risk & Not shared & Charged by the private part. \\
\hline Criteria of Purpose & No (min price) & No direct effect on PA's balance sheet. \\
\hline Economy & No (min output/input) & $\begin{array}{l}\text { The public part does not improve its managerial skills and } \\
\text { competences in the definition and management of the project. }\end{array}$ \\
\hline $\begin{array}{l}\text { Efficiency } \\
\text { Effectiveness }\end{array}$ & Yes (max cost/benefit) & \begin{tabular}{l} 
Low control by the PA on warranty of public utility purposes. \\
\hline
\end{tabular}
\end{tabular}

\subsection{Innovative Contractual and Financial Tools for Real Estate Enhancement}

Innovative enhancement tools include: (i) contractual tools (i.e., administrative barter); (ii) financial tools (i.e., civic crowdfunding).

The "interventions of horizontal subsidiarity" [58] and the institution of administrative barter (according to article 190 Legislative Decree no. 50/2016, which supplements and modifies the provisions of art. 24 D. Law no. 133/2014, "Unblock Italy"), propose community participation in the enhancement of unused places and assets through cultural initiatives, interventions of urban decorum, recovery, and reuse for general interest purposes. The management is entrusted to a consortium that reaches at least $66 \%$ of the ownership of the area.

Crowdfunding is, instead, the practice of funding a project by raising amounts of money from a large number of people - the "crowd" - typically via an on-line platform (e.g., "www.kickstarter.com", "www.startnext.de" and "www.fundrise.com"). We refer to civic crowdfunding for projects related to a specific territorial area with strong attractiveness and/or with a rooted sense of place and belonging among the community [59]. Table 12 assesses innovative contractual and financial tools according to the proposed taxonomy of criteria; the results confirm that these tools are not advisable for PAs looking for strong financial benefits. 
Table 12. Analysis of innovative contractual and financial tools (e.g., administrative barter or civic crowdfunding) for enhancement. Authors' elaboration.

\begin{tabular}{|c|c|c|}
\hline Criteria & Metrics & Qualitative Assessment \\
\hline \multicolumn{3}{|l|}{ Endogenous Criteria } \\
\hline Dimensional scale & Low & $\begin{array}{l}\text { No specification, but being a subsidiary procedure is expected } \\
\text { to be used for single assets or restricted public spaces. }\end{array}$ \\
\hline Use & Used/Underused/Not used & Usually for specific abandoned areas. \\
\hline $\begin{array}{l}\text { Profitability of assets' } \\
\text { destination of use }\end{array}$ & Cold/warm & Usually not profitable. \\
\hline $\begin{array}{l}\text { Presence of planning } \\
\text { constraints/identity value }\end{array}$ & High & Areas of public interest, so with a medium/high identity value. \\
\hline Time required & High & Speed strategy, thanks to the facilitations given by law. \\
\hline Actors to be involved & Low & $\begin{array}{l}\text { At least the PA, the private organization of citizens, (and the } \\
\text { eventual online platform manager in the case of crowdfunding). }\end{array}$ \\
\hline Sharing of the risk & Not shared & Given to the private part. \\
\hline \multicolumn{3}{|l|}{ Criteria of Purpose } \\
\hline Economy & No (min price) & $\begin{array}{l}\text { Costs and revenues are in the hand of the private part } \\
\text { (consortium of citizens). }\end{array}$ \\
\hline Efficiency & No (min output/input) & $\begin{array}{l}\text { No need for resources from the public administration. It is not } \\
\text { yet clear whether forms of public evidence are necessary. }\end{array}$ \\
\hline Effectiveness & Yes (max cost/benefit) & $\begin{array}{l}\text { Yes, because of a total absence of costs for the PA and a total } \\
\text { meeting with the demand related to that specific place or } \\
\text { building. }\end{array}$ \\
\hline
\end{tabular}

\section{Discussion}

As can be seen from the analysis, the process of enhancing the value of assets is a complex and articulated process that requires, on the one hand, specific expertise and, on the other, the systematization of criteria and multi-criteria decision-making processes that regulate and combine the needs imposed by the budget and the mission of the public body. The criteria proposed in this research contribute to the debate on optimization of PAs' use of their real estate to raise capital, save costs and provide better services to citizens $[18,60]$.

The research proposes the taxonomy of guiding criteria as a platform that rationalizes and systematizes endogenous criteria and criteria of purpose with the enhancement strategies and methods available in Italy. This provides a tool to support the PA in order to proceed in the evaluation of the feasibility of the enhancement path on the basis of available resources and the purpose to be achieved.

Indeed, from the analysis, what is clear is that the decision-making process of PAs for selecting a suitable enhancement strategy or tool should rest on the specific technical features of each public asset, the public utility aim that the public entity intends to pursue, the needs of the community (i.e., the demand of public services), and the skills available within the PA, that is, promoting the strategy [61]. Apart from the endogenous criteria (which derive from the functioning of the instrument and, for these reasons, do not allow space for comparability, if not in the sense of requirements) it is possible to reflect on the "purpose" criteria in future research developments. Thus, the final aim of a public real estate enhancement strategy should be to "create value" [62], not only in economic terms, but the measurability of this "value" remains, for now, a blurred concept.

The task that today's Public Administrations are called upon to perform requires a systemic approach to problem-solving and, above all, professional skills oriented towards a managerial approach at the strategic and operational levels [63]. Since public real estate management is performed according to country-specific procedures [64], this article strongly refers to Italian laws and regulations for public real estate enhancement. The 
results of this study are, therefore, not fully generalizable and require adjustments to be applied in other countries, although they can serve as a reference. The research, presented as a viewpoint, deserves a margin for improvement: the results achieved to date lay the foundations for a more virtuous and efficient action of the PA in the management of the public built environment and in pursuit of the objective of public utility. Future research developments are likely to test the usability and applicability of the taxonomy of criteria on real cases during pre-feasibility phases of a public real estate enhancement procedure, and to test the assumptions in this research according to a more robust methodology.

Author Contributions: Conceptualization, A.M., G.C., M.M.; methodology, A.M., G.C.; validation, S.M., M.M.; formal analysis, A.M., G.C.; investigation, A.M., M.M., S.M., G.C.; writing-original draft preparation, A.M.; writing-review and editing, A.M., G.C., M.M., S.M.; supervision, M.M., S.M. All authors have read and agreed to the published version of the manuscript.

Funding: This research received no external funding.

Institutional Review Board Statement: Not applicable.

Informed Consent Statement: Not applicable.

Data Availability Statement: Data sharing not applicable.

Acknowledgments: The authors would like to acknowledge the Italian State Property Agency (Agenzia del Demanio) for the support in this research.

Conflicts of Interest: The authors declare no conflict of interest.

\section{References}

1. Fabrizi, C.; Pico, R.; Casolaro, L.; Graziano, M.; Manzoli, E.; Soncin, S.; Esposito, L.; Saporito, G.; Sodano, T. Mercato immobiliare imprese della filiera e credito: Una valutazione degli effetti della lunga recessione. Quest. Econ. 2015, 263, 1-57.

2. Trojanek, M. Strategic municipal real estate management. J. Int. Study 2015, 8, 9-17. [CrossRef] [PubMed]

3. Gross, M.; Źróbek, R. Good governance in some public real estate management systems. Land Use Policy 2015, 49, 352-364. [CrossRef]

4. Irelli, V.C. Proprietà Pubblica e Diritti Collettivi; Cedam: Padova, Italy, 1983.

5. Samuelson, P.A. The Pure Theory of Public Expenditure. Rev. Econ. Stat. 1954, 36, 387-389. [CrossRef]

6. United Nations. Transforming Our World: The 2030 Agenda for Sustainable Development. 2015. Available online: https: / / sustainabledevelopment.un.org/content/documents/21252030\%20Agenda\%20for\%20Sustainable\%20Development\% 20web.pdf (accessed on 20 December 2020).

7. Cottarelli, C. Il Macigno. Perché il Debito Pubblico ci Schiaccia e Come si fa a Liberarsene; Feltrinelli: Roma, Italy, 2016.

8. Carbonara, S.; Stefano, D. An Operational Protocol for the Valorisation of Public Real Estate Assets in Italy. Sustainability 2020, 12, 732. [CrossRef]

9. Vianello, D. Small steps to emerge from the tunnel. J. Technol. Archit. Environ. 2012, 45-54. [CrossRef]

10. Carpenter, A.; Corrigan, B.; Levitt, R.; Stephen, P. Ten Principles for Creating Value from Local Government Property; The Urban Land Institute: Washington, DC, USA, 2006.

11. Deakin, C. Property Management: Corporate Strategies, Financial Instruments and the Urban Environment; Ashgate Publishing Ltd.: Aldershot, UK, 2004.

12. Andersson, L. Cooperation between Public and Private Players in the Swedish Public Real Estate Sector: Motives and Contract Types. In Proceedings of the 16th Annual European Real Estate Society Conference, ERES: Conference, Stockholm, Sweden, 24-27 June 2009.

13. Kaganova, O.; Nayyar-Stone, R. Municipal real property asset management: An overview of world experience, trends and financial implications. J. Res. Estate Portf. Manag. 2000, 6, 307-326. [CrossRef]

14. Vermiglio, C. Public property management in Italian municipalities. Prop. Manag. 2011, 29, 423-442.

15. Kaganova, O.; McKellar, J. Managing Government Property Assets: International Experiences; The Urban Institute Press: Washington, DC, USA, 2006.

16. Fecchio, A. Le competenze gestionali elemento strategico nella fase decisionale della valorizzazione immobiliare. TECHNE J. Technol. Archit. Environ. 2012, 3, 65-75.

17. Mangialardo, A.; Micelli, E. Reconstruction or Reuse? How Real Estate Values and Planning Choices Impact Urban Redevelopment. Sustainability 2020, 12, 4060. [CrossRef]

18. Filipkowska, A.W.; Rymarzak, M. Decision-making in corporate and municipal asset management. Int. J. Res. Estate 2013, 8, 17-29. 
19. Gibson, V. Strategic Property Management: How Can Local Authorities Develop a Property Strategy? Prop. Manag. 1994, 12, 9-14. [CrossRef]

20. Agenzia del Demanio, Strategie e Strumenti per la Valorizzazione del Patrimonio Immobiliare Pubblico. 2015. Available online: http:/ / www.affariregionali.it/media/169644/studio-demanio-finale_new.pdf (accessed on 20 July 2020).

21. Ministero di Economia e Finanze (MEF). Rapporti Annuali Immobili. 2019. Available online: http://www.dt.mef.gov.it/modules/ documenti_it/patrimonio_pubblico/patrimonio_pa/RapportoImmobili_DatiAnno2017.pdf (accessed on 20 July 2020).

22. Anselmi, L. L'azienda Comune: Principi e Metodologie Economico Aziendali Per Gli Enti Locali (Con Riferimenti Alle Province ed Alle Comunità Montane); Maggioli Editore: Rimini, Italy, 2001.

23. Istat. La Ricchezza Non Finanziaria in Italia. Stima del Valore Delle Principali Attività Non Finanziarie Per Settore Istituzionale. 2019. Available online: https:/ / www.istat.it/it/archivio/208722 (accessed on 20 July 2020).

24. Festa, G. Riflessioni Sulla Contabilità Degli enti Pubblici; Editore Key: Milano, Italy, 2016.

25. Legislative Decree no. 351/2001: “Urgent Provisions on Privatization and Valorization of Public Real Estate Assets and Development of Real Estate Investment Funds". Available online: http:/ /www.parlamento.it/519 (accessed on 20 July 2020).

26. Article 2, Legislative Decree no. 85/2010, Allocation of Its Own Assets to Municipalities, Provinces, Metropolitan Cities and Regions in Accordance with Article 19 of Law no. 42/2009. Available online: http:/ / www.parlamento.it/519 (accessed on 20 July 2020).

27. GRUPPO NAZCA-il Rapporto Pubblico-Privato Nella Rigenerazione Urbana, un Nuovo Punto di Vista. Available online: Www.grupponazca.wordpress.com (accessed on 20 July 2020).

28. OPPAL-Osservatorio Permanente Pubblica Amministrazione Locale. Available online: https://www.rec.polimi.it/offertaformativa/oppal/ (accessed on 20 July 2020).

29. Budäus, D.; Buchholtz, K. Controlling Local Government Cost and Performance: An International Comparison. In Research in Governmental and Nonprofit Accounting; Chan, J.L., Jones, R.H., Lüder, K.G., Eds.; JAI Press: Greenwich, CT, USA, 1996; Volume 9, pp. 33-57.

30. Ewalt, J. Theories of governance and new public management: Links to understanding welfare policy implementation. In Proceedings of the Annual Conference of the American Society for Public Administration, Newark, NJ, USA, 17 March 2001.

31. Hood, C. A public management for all season? Public Adm. 1991, 69, 3-19.

32. Koolman, J.; Van Vliet, M. Governance and Public Management. In Managing Public Organizations: Lessons from Contemporary European Experience; Eliassen, K.A.M., Koolman, J., Eds.; Sage: London, UK, 1993.

33. Kickert, W.J.M.; Klijn, E.H.; Koppenjan, J.F.M. Managing Complex Networks Strategies for the Public Sector; Sage: London, UK, 1997.

34. Jones, L.L.; Thompson, F. L'implementazione strategica del New Public Management. Azienda Pubblica 1997, 6, 567-586.

35. Rebora, G. Un Decennio di Riforme. Nuovi Modelli Organizzativi e Processi di Cambiamento Delle Amministrazioni Pubbliche; Guerini: Milano, Italy, 1999.

36. Mascarenhas, R.C. Building an Enterprise Culture in the Public Sector: Reform of the Public Sector in Australia, Britain, and New Zealand. Pub. Admin. Rev. 1993, 53, 319-328. [CrossRef]

37. Chapter V, Legislative Decree no. 267/2000 "Unified Text of the Laws on the Regulation of Local Authorities". (Here we make Reference to Specific Chapter V of the Law, so We Think We Can Maintain Two Separate References.). Available online: http:/ / www.parlamento.it/519 (accessed on 20 July 2020).

38. Brugnoli, A. Valorizzazione dei patrimoni immobiliari come strumento per finanziare gli investimenti delle amministrazioni pubbliche locali: Strategie di riferimento, casi rilevanti e modelli emergenti. In Primo Rapporto Sulla Finanza Pubblica. Finanza Pubblica e Federalismo; Nicolai, M., Ed.; Maggioli Editore: Rimini, Italy, 2012.

39. Articles 33 and 33-bis, Legislative Decree no. 98/2011: "Provisions on the Enhancement of Real Estate". Available online: http:/ / www.parlamento.it/519 (accessed on 20 July 2020).

40. Decree of the President of the Republic of 13 September 2005, no. 296: "Regulations Concerning the Criteria and Procedures for the Granting of Concessions for the Use and Rental of Real Estate Belonging to the State". Available online: http:/ / www. parlamento.it/519 (accessed on 20 July 2020).

41. Legislative Decree no. 50/2016: "Public Procurement Code". Available online: http://www.parlamento.it/519 (accessed on 20 July 2020).

42. Article 180, Legislative Decree no. 50/2016 "Public Procurement Code". Available online: http://www.parlamento.it/519 (accessed on 20 July 2020).

43. IFEL. Il Patrimonio Immobiliare Degli Enti Locali: Strumenti. 2013. Available online: www.fondazioneifel.it (accessed on 20 July 2020).

44. Norsa, A.; Trabucco, D. Il leasing in costruendo, una nuova opportunità per le opere pubbliche. TECHNE J. Technol. Archit. Environ. 2012, 3, 90-96.

45. Article 14-bis, Law No 86/1994: "Establishing and Regulating Closed-End Real Estate Investment Funds". Available online: http: / /www.parlamento.it/519 (accessed on 20 July 2020).

46. Articles 53-57-bis, Legislative Decree no. 42/2004 "Alienation and Other Modes of Transmission". Available online: http: / / www.parlamento.it/519 (accessed on 20 July 2020).

47. Brancaccio, S. Il Sistema Integrato di Fondi Immobiliari Per L'edilizia Privata Sociale. 2011. Available online: https://www. cdpisgr.it/includes/pdf/brancaccio.pdf (accessed on 20 July 2020). 
48. Article 145 and 153, Legislative Decree no. 163/2006 “Code for Public Contracts for Works, Services and Supplies". Available online: http:/ / www.parlamento.it/519 (accessed on 20 July 2020).

49. Legislative Decree no. $267 / 2000$ "Unified Text of the Laws on the Regulation of Local Authorities". Available online: http: / / www.parlamento.it/519 (accessed on 20 July 2020).

50. Article 156, Legislative Decree no. 163/2006 “Code for Public Contracts for Works, Services and Supplies". Available online: http:/ / www.parlamento.it/519 (accessed on 20 July 2020).

51. Article 120, Legislative Decree no. 267/2000 “Consolidation Text of the Laws on Local Government Regulations". Available online: http:/ / www.parlamento.it/519 (accessed on 20 July 2020).

52. Mello, D. STU Quali, Come e Perchè? A Dieci Anni dal d.Lgs 267/2000; Inu Edizioni: Roma, Italy, 2011.

53. Law no. 296/2006 "Provisions for the Establishment of the Annual and Multi-Annual Budget of the State". Available online: http:/ / www.parlamento.it/519 (accessed on 20 July 2020).

54. Article 188, Legislative Decree no. 50/2016: "Public Procurement Code". Available online: http://www.parlamento.it/519 (accessed on 20 July 2020).

55. Article 160-ter, Legislative Decree no. 163/2006: “Code for Public Contracts for Works, Services and Supplies". Available online: http:/ / www.parlamento.it/519 (accessed on 20 July 2020).

56. Law no. 133/2014, “Urgent Measures for the Opening of Construction Sites, the Construction of Public Works, the Digitization of the Country, Bureaucratic Simplification, the Emergency of Hydrogeological Instability and for the Resumption of Production Activities". Available online: http:/ / www.parlamento.it/519 (accessed on 20 July 2020).

57. Valaguzza, S. Le sponsorizzazioni pubbliche: Le insidie della rottura del binomio tra soggetto e oggetto pubblico e la rilevanza del diritto interno. Riv. Ital. Dirit. Pubblico 2015, 5, 1381-1394.

58. Article 189 Legislative Decree no. 50/2016 “Public Procurement Code" (Part IV). Available online: http://www.parlamento.it/519 (accessed on 20 July 2020).

59. Morena, M. Waterfront: Innovative Strategies and Tools for the Enhancement of Cities and Territories; Maggioli Editore: Rimini, Italy, 2020.

60. Kaganova, O. Integrating Public Property in the Realm of Fiscal Transparency and AntiCorruption Efforts. In Finding the Money: Public Accountability and Service Efficiency through Fiscal Transparency, Local Government and Public Service Reform Initiative; Peteri, G., Ed.; Open Society Institute (OSI): Budapest, Hungary, 2008; pp. 209-235.

61. Migliore, A. Valorisation of Public Real Estate, from Strategies Selection to the Proposal of a Procedural Model for Enhancement. Master's Thesis, Politecnico di Milano, Milano, Italy, 2019.

62. Moore, M.H. Creating Public Value; Harvard University Press: Cambridge, MA, USA, 1995.

63. Dowall, D.E. The Public Real Estate Development Process. J. Am. Plan. Assoc. 1990, 56, 504-512. [CrossRef]

64. Gross, M.; Źróbek, R.; Špirková, D. Public Real Estate Management System in the Procedural Approach-A Case Study of Poland and Slovakia. Real Estate Manag. Valuat. 2014, 22, 63-72. [CrossRef] 